Vol. 5 (3), pp. 048-052, June, 2015

ISSN: 2276-7797; ICV: 5.98

Copyright (C2015, the copyright of this article is retained by the author(s)

DOI Link: http://doi.org/10.15580/GJMS.2015.3.030815042

http://gjournals.org/GJMS

\title{
Dipstick Urinalysis in Apparently Healthy Neonates in Port Harcourt
}

\section{*1YAGUO Ide Lucy Eberechukwu, 10PARA Peace lbo, ${ }^{1}$ UCHENWA-ONYENEGECHA Tochi Ada}

${ }^{1}$ Department of Paediatrics and Child Health, University of Port Harcourt Teaching Hospital. Port Harcourt, Rivers State, Nigeria, West Africa P.M.B 6173.

\section{ARTICLE INFO}

Article No.: 030815042

Type: Research

DOI: 10.15580/GJMS.2015.3.030815042

Submitted: 08/03/2015

Accepted: 10/06/2015

Published: 20/06/2015

${ }^{\star}$ Corresponding Author

Yaguo Ide Lucy Eberechukwu

E-mail: lucyaguolucy@gmail.com

Phone: +2348109864336

Keywords:

Dipstick urinalysis, healthy, neonates
Background: Dipstick urinalysis, which is a simple but very important diagnostic procedure in paediatric nephro-urology, provides information about multiple physicochemical properties of urine. It detects common urinary abnormalities in children which could result from a wide range of conditions. Proteinuria, haematuria and glycosuria for example may be pointers to serious underlying pathologies in the newborn. This study was undertaken to determine baseline findings on dipstick urinalysis in healthy neonate in Port Harcourt as there is paucity of such a study in our environment.

Methods: This descriptive study was conducted in the post natal wards of the University of Port Harcourt Teaching Hospital. Dipstick urinalysis was carried out on clean catch urine samples from $\mathbf{1 8 0}$ healthy full-term and near term breast-fed neonates, without maternal morbidities or personal pathological antecedents within the first $\mathbf{4 8}$ hours of life.

Results: Gestational ages ranged from $35-42$ weeks mean of $38.54 \pm 1.38$, mean birth weight of $3.26 \pm 0.55 \mathrm{~kg}$ and a male: female ratio of 1: 1.1. Haematuria glycosuria and ketonuria were not identified in any baby. All urine samples were also negative for nitrites and leucocytes. Proteinuria was present in $3(1.7 \%)$ of the babies.

Conclusion: Haematuria, glycosuria and ketonuria are not common in apparently healthy neonates in Port Harcourt. Presence of nitrites and leucocytes are unusual. Proteinuria, haematuria and glycosuria in the neonates should be further investigated for underlying pathologies. 


\section{INTRODUCTION}

Urinalysis is recognized as a simple and inexpensive method for screening healthy children for renal abnormalities and the dipstick method is the most commonly implemented procedure. Shagari et al (2007), Whiting et al (2006) It is easy to perform and does not require sophisticated training of personel. Whiting et al (2006), Mcpherson (2007) Urinary abnormalities are commonly detected in children and could result from a wide range of conditions Mc Taggart (2005) or may be transient in some cases.Mcpherson (2007)

Dipstick urinalysis provides information about multiple physiochemical properties of urine. Mcpherson (2007) Abnormal dipstick urinalysis can result from pathologic and non pathologic causes although not all abnormal results are clinically significant as false positive and negative results are also common.Patel (2006)

Proteinuria and haematuria are amongst the early manifestations of renal disease, in general proteinuria is more significant than haematuria. Akor et al (2009) Studies have shown that positive urine test for proteinuria and /or haematuria were significant predictors of end stage renal disease. Iseki et al(1996), Gansevoort et al (2006) Nitrite and leucocyte in urine can be used to diagnose urinary tract infection(UTI) which may be subclinical or present with non specific symptoms or signs and have potential for serious long term complications if not treated promptly.Gorelick and Shaw(1999), Whiting et al (2005) It has been shown that , the result from dipstick urinalysis alone compares favourably with combination of urinalysis and urine culture in diagnosis of urinary tract infection among febrile neonates suggesting that dipstick urinalysis alone may be an adequate screening test for UTI. Glissmeyer et al (2014) Biliubinuria is a reflection of conjugated hyperbilirubinaemia and tends to suggest obstructive jaundice (intra and extra hepatic). Ibe (2007).

In neonates, renal abnormalities may be traced to specific inherited or congenital problems or to intrauterine or postnatally acquired events.Guignard and Drukker(2000) Routine newborn urinalysis screening is not practiced in most hospitals and studies on dipstick urinalysis among apparently healthy neonates are limited in southern Nigeria. This study aims to determine baseline findings on dipstick urinalysis among apparently healthy newborns in Port Harcourt.

\section{MATERIALS AND METHODS}

This descriptive study was conducted in the post natal wards of the University of Port Harcourt Teaching
Hospital over a 6month period, from January to June 2013.

Informed consent was obtained from the parents/caregivers before recruiting subjects for the study. Voided urine samples were obtained within the first 48hours of life from 180 apparently healthy full term and near term breastfed newborns who had a normal perinatal period. Neonates with maternal morbidity or personal pathological antecedents like antenatally diagnosed hydronephrosis or congenital anomalies were excluded.

The urine samples were collected by clean catch method. Appearance and colour of the urine, were noted and the urine immediately tested by the dipstick method using Coombi 10 reagent strips. Parameters tested included $\mathrm{PH}$, specific gravity, protein, blood, glucose, leucocyte, nitrite, urobilinogen, bilirubin and ketone. The results of dipstick tests were recorded as $( \pm)$ for trace; $(1+),(2+)$, and $(3+)$ for varying degrees of proteinuria; normal, negative $(-)$ or positive $(+)$ for urobilinogen for other parameters ( blood, ketone, glucose, bilirubin, nitrite and leucocyte). Proteinuria of 1+or more was considered significant.

Data was analysed using SPSS version 16.0 and presented as simple frequencies and in tables. Patients with significant abnormalities were referred to the nephrology unit for further evaluation.

\section{RESULTS}

There were 180 subjects. Table 1 shows the demographic characteristics of the study population. There were 85 males (47.2\%) and 95 females (52.8\%) with a male: female ratio of $1: 1.1$. Gestational ages ranged from $35-42$ weeks with mean of $38.54 \pm 1.38$. The birth weights ranged from $1.8-4.6 \mathrm{~kg}$ with mean birth weight of $3.26 \pm 0.55 \mathrm{~kg}$. The APGAR scores at 1 and 5 minutes ranged from 4-10 and 6-10 with mean of 7.88 \pm 1.09 and $9.24 \pm 0.76$ respectively.

Table 1 shows the demographic characteristics of the 180 apparently healthy newborns and Table 2 shows the dipstick urinalysis findings. Proteinuria was present in 3(1.7\%) babies, 2 males and 1 female, all of which had trace proteinuria. Bilirubinuria was present in $11(6.1 \%)$ babies and all the babies who had bilirubinuria had normal urobilinogen in their urine. Haematuria, glucosuria and ketonuria were not identified in any baby and all urine samples were negative for nitrite and leucocyte. The urine $\mathrm{pH}$ ranged between 2-6, 4 babies had urine $\mathrm{pH}$ of 2 while 112 and 64 babies had urine $\mathrm{pH}$ of 5 and 6 respectively. The specific gravity (SG) of urine ranged from 1.010-1.020, 128 babies had SG of 1.010, 35 babies had SG of 1.015 and 17 had SG of 1.020 . 
Table 1: Demographic characteristics among 180 apparently healthy newborns

\begin{tabular}{|l|l|l|}
\hline DEMOGRAPHIC FEATURES & \multicolumn{2}{|l|}{} \\
\hline GESTATIONAL AGE & NUMBER OF SUBJECTS & PERCENTAGE \\
\hline $35-36 w k s$ & 10 & 5.6 \\
$37-38 w k s$ & 82 & 45.5 \\
39-40wks & 78 & 43.3 \\
>40wks & 8 & 4.5 \\
Missing & 2 & 1.1 \\
\hline Total & 100 & 100.0 \\
\hline GENDER & & \\
$\quad$ Male & 85 & 47.2 \\
\hline Female & 95 & 52.8 \\
\hline
\end{tabular}

Table 2: Urinalysis findings amongst the newborns studied

\begin{tabular}{|l|l|l|l|}
\hline s/n & URINALYSIS FINDINGS & Frequency & Percentages (\%) \\
\hline 1 & pH & & \\
& 2 & 4 & 2.2 \\
& 5 & 112 & 62.2 \\
& 6 & 64 & 35.6 \\
\hline 2 & Specific gravity & & \\
& & 128 & \\
& 1.010 & 35 & 71.1 \\
& 1.015 & 17 & 19.4 \\
& 1.020 & 3 & 9.4 \\
\hline 3 & Proteinuria & 11 & 1.7 \\
\hline 4 & Bilirubinuria & 0 & 6.1 \\
\hline 5 & Glucosuria & 0 & 0 \\
\hline 6 & Leucocytes & 0 & 0 \\
\hline 7 & Haematuria & 0 & 0 \\
\hline 8 & Nitrites & 0 & 0 \\
\hline 9 & Urobilinogen & 0 & 0 \\
\hline 10 & ketonuria & & 0 \\
\hline
\end{tabular}

\section{DISCUSSION}

The dipstick method is the most rapid screening procedure used in early detection of urinary tract diseases thus helping prevention and slowing progression to chronic kidney disease(CKD) Hajar et al(2011),Deville et al (2004). Our study revealed that 18 $(10 \%)$ of the newborns had urine abnormalities: $3(1.7 \%)$ had proteinuria, $11(6.1 \%)$ bilirubinuria and $4(2.2 \%)$ very low urine $\mathrm{pH}$ of 2 which was significant and therefore suggests that routine screening of apparently healthy newborns for urinary abnormalities is justified. The percentage of urine abnormalities in this study is higher than the prevalence cited by Falakaflaki et al(2011).This may be attributable to the fact that more urine abnormalities were tested for in our study.

Proteinuria and haematuria are important laboratory signs of renal disease.Akor et al(2009), Leung and Wong (2010). Proteinuria is considered an independent risk factor for CKD and thus warrants attention for early detection and prompt management.EITaayeb et al(2010), Johnson et al(2012) In our study, none of the babies had significant proteinuria as all the $3(1.7 \%)$ babies had trace of protein in their urine. This contrasts with the report from a similar study carried out by Adedoyin et al(2000) among newborns in Illorin, Nigeria where proteinuria was identified in $77.5 \%$ of babies, this may be attributable to the high percentage of preterms $(75 \%)$ among the babies studied. Falakaflaki et al (2011)however in their study among full term newborns reported that $5.75 \%$ of the babies had significant proteinuria. The reason for this is not clear but may suggest possible environmental /racial differences in proteinuria or probably because they had a larger sample size of 400 compared to ours with sample size of 180. In one study done by lkimalo et al(2003) among 1010 asymptomatic children aged 6-17 years in Port Harcourt to screen for haematuria and proteinuria, the prevalence of significant proteinuria was $1 \%$ which was lower than the prevalence of $4.72 \%$ and $3.5 \%$ reported by Abdurrahaman et $\mathrm{al}(1978)$ and Akor et al(2009) respectively among similar age group in other parts of the country. This lower prevalence in our study and Ikimalo et al(2003) may suggest some environmental influence on the prevalence of Proteinuria. Proteinuria occurred more commonly in males which is in agreement with the findings in the study by Falakaflaki et al(2011). Haematuria was not seen in any baby in our 
study and is consistent with the findings of Edelmann et al(1973). Falakaflaki et al (2011) however reported very low prevalence of $0.25 \%$ (only one baby had haematuria). This may suggest that the finding of haematuria in the newborn should be further evaluated.

Glucosuria was not identified in any baby, this is consistent with the findings of Falakaflaki et al(2011) but contrasts with the report by Rhodes et al ${ }^{24}$ where glucosuria was seen in as high as $24 \%$ of babies. The reason for this disparity is not readily explainable. In another study conducted by Alharthi et al(2014) to screen for urine abnormalities among preschool children aged 3-6 years in western Saudi Arabia, glucosuria was seen in $0.6 \%$ of children. This difference may probably be because of the different age group studied.

The presence of bilirubinuria which is a reflection of conjugated hyperbilirubinaemia tends to suggest obstructive jaundice. Ibe(2007). In our study $11(6.1 \%)$ babies had bilirubinuria. This cannot readily be explained because these babies were apparently normal and had normal urobilinogen in their urine. All urine samples were negative for nitrite and leucocyte in our study. On the contrary in a study done by Nebigil and Tumar(1992) to determine the prevalence of asymptomatic urinary tract infection among apparently healthy children aged 1 day to 16 years, prevalence of $4 \%$ was reported among the newborns. The difference may be because of the difference in the ages of the newborns studied since we studied only newborns within the 1 st 48 hours of life.

Some studies have concluded that routine urine screening of infants is not very useful and should be performed only at ages 5 and above Abdurrahaman et al (1978), Simonetti and Konrad(2006)while others suggested that all patients should have routine urinalysis to identify the presence of unrecognized renal disease which may benefit from simple therapeutic measures. Kanef et al(2006) Routine urine screening in newborns is in no doubt helpful in diagnosis of underlying renal diseases in neonates and is cost effective and simple to perform.

\section{CONCLUSION}

Mild proteinuria may be seen in the normal newborn within the first 72 hours of life however, the finding of significant proteinuria in newborns warrants repeat urinalysis to determine if it is transient or pathologic. Haematuria and glucosuria should also be further investigated for underlying pathologies. Presence of nitrites and leucocytes in the urine are unusual in apparently healthy neonates

\section{RECOMMENDATION}

Dipstick urinalysis should be done routinely for newborns. Babies with urine abnormalities, should be further evaluated to ascertain if such abnormalities are transient or actually pathologic so that such babies can be treated early to prevent or reduce associated morbidities.

\section{REFERENCES}

Abdurrahman MB, Chakrabarty DP, Ochoga SA (1978). Bacteriuria and other urinary abnormalities among primary school children in Kaduna. Nig J Paediatr 5: 21-24.

Adedoyin OT, Akindele JA, Ajayi OA, Okesina AB (2000). Urinalysis in clinically stable Nigerian Newborns. Nig J Paediatr 27(1-2):1-5.

Akor F, Okolo SN, Agaba El, Okolo A (2009). Urine examination findings in apparently healthy new school entrants in Jos, Nigeria. SAJCH 3: 60-63.

Alharthi AA, Taha AA, Edrees AE, Elnawawy AN, Abdelrahman AH (2014). Screening for urine abnormalities among children in Western Saudi Arabia. Saudi Med J 35: 1477-1481.

Devillé W, Yzermans J, Van Duijn N, Bezemer PD, Van der Windt D, Bouter LM (2004). The urine dipstick test useful to rule out infections. A meta-analysis of the accuracy. BMC Urology 4:4.

Edelmann CM, Ogwo JE, Fine BP, Martinez AB (1973). The prevalence of bacteriuria in full term and premature newborn infants. J Pediatr 82: 125-132.

El-Taayeb M, El Setouhy M, ElSayed H, ELshahawy Y (2010). Screening of proteinuria in young adults. Is it worthwhile/ Dialysis Transpl 39:522-526.

Falakaflaki B, Mousavinasab SN, Mazloomzadeh S (2011). Dipstick urinalysis screening of healthy neonates. Pediatr Neonatol 52:161-164.

Gansevoort RT. Bakker SJL, de Jong PE (2006). Early detection of progressive chronic kidney disease : is it feasible [comment]. J Am Soc Nephrol 17: 12181220.

Glissmeyer EW, Korgenski EK, Wilkes J, Schunk JE, Sheng X, Blaschke AJ et al (2014). Dipstick screening for urinary tract infection in febrile infants. Pediatrics 133: 1121-1127.

Gorelick M, Shaw KN (1999). Screening tests for urinary tract infection in children: A meta-analysis. Pediatrics 104:54.

Guignard JP, Drukker A. Clinical neonatal nephrology. In: Barratt TM, Avner ED, Harmon WE eds. Pediatric Nephrology. $4^{\text {th }}$ edition. Lippincott Williams \& Wilkins; 2000;p. 1051-1066.

Hajar F, Taleb M, Aoun B, Shatila A (2011). Dipstick Urine analysis screening among asymptomatic school children. North Am J Med Sci 3:179-184.

Hanef R,Ally SH, Julal-ud-din, Khan K (2006). Effectiveness of routine urinalysis of patient attending rural health centers in Abbottabad. J Ayub Med Coll Abbottabad 18:63-64.

Ibe BC. Neonatal Jaundice. In: Azubuike J.C, Nkanginieme KEO. Editors. Paediatrics and Child 
Health in a Tropical Region. $2^{\text {nd }}$ edition. University of Port Harcourt Press. 2007;p209-210.

Ikimalo FE, Eke FU, Nkanginieme KEO, Ikimalo J (2003). Urinary screening for detection of asymptomatic haematuria and proteinuria in children in urban and periurban schools in Port Harcourt. Nig J Paediatr 30:1-6.

Iseki K, Iseki C, Ikemiya Y, Fukiyama K (1996). Risk of developing end stage renal disease in a cohort of mass screening. Kidney Int 49: 800-805.

Johnson DW, Jones GRD, Mathew TH, Ludlow MJ, Chadban SJ, Usherwood T et al (2012). Chronic Kidney Disease and measurement of albuminuria or proteinuria: a position statement. Med $\mathrm{J}$ Aust 197:224-225.

Leung AK, Wong AH (2010). Proteinuria in children. Am Fam Physician 82:645-651.

Mcpherson AR, Ben-Ezra J, Zhao S. Basic examination of urine. In: Mcpherson AR, Pincus RM editor. Henry's Clinical Diagnosis and Management by Laboratory Methods. $21^{\text {st }}$ edition. Philadelphia, PA: WB Saunders; 2007; p. 393-425.

McTaggart S (2005). Childhood urinary conditions. Aust Fam Physician 34: 937-941.

Nebigil I, Tumar N (1992). Asymtomatic urinary tract infection in childhood. Eur J Pediatr 151:308-309.
Patel HP (2006). The Abnormal Urinalysis. Pediatr Clin North Am 53: 325-337.

Rhodes PG, Hammel CL, Berman LB (1962). Urinary constituents of the newborn infant. J Pediatr 60: 1823.

Shajari A, Zadeh FMH, Shajari H (2007). screening of renal diseases in the first primary school children in Shiraz. Acta Medica Iranica 45: 215-218. Available from:

http://acta.tums.ac.ir/index.php/acta/article/download 3205/2891.

Simonetti GD, Konrad M (2006). Examination of urine in the child. Ther Umsch 63:579-584.

Whiting P, Westwood M, Bojke L, Palmer S, Richardson G, Cooper J et al (2006). Clinical effectiveness and cost-effectiveness of tests for the diagnosis and investigation of urinary tract infection in children: a systematic review and economic model. Health Technol Assess 10:iii-iv, xi-xiii, 1-154.

Whiting P, Westwood M, Watt I, Cooper J, Kleijnen J (2005). Rapid tests and urine sampling techniques for the diagnosis of Urinary tract infection in children under five years: a systematic review. BMC Pediatrics 5:4. 